\title{
Vowel Harmony and Other Morphological Processes in Turkish
}

\author{
Eyüp Bacanl1, Darin Flynn \& Amanda Pounder*
}

\begin{abstract}
Vowel harmony appears to be a regular phonological process in Turkish, but nevertheless is not exceptionless. Due to these exceptions, it cannot be considered as part of the active phonology of Turkish. An analysis is proposed in which morphology and lexicon control vowel harmony and other processes similar in this regard. Morphology is unlike other modules of grammar in requiring access to all of syntactic, semantic, and phonological properties to function. One of the roles of morphology is to give commands to the phonology during formation of a complex word, such as "Carry out vowel harmony!" The phonology need not account for why such a command does not accompany certain suffixes, why it does not apply to all roots, nor why other commands only accompany a few suffixes. More generally, there is no need for phonology to access morphological information in a modular model of grammar.
\end{abstract}

Keywords. Turkish; vowel harmony; morphologically-conditioned phonology; morphology; phonology; exceptionality

1. Introduction. Phonologists often distinguish bona fide phonology such as Turkish's "very general rule of progressive vowel harmony" (Inkelas 2011:69) from morphologically-conditioned phonology (MCP) such as "the deletion of stem-final $k$ " (ibid.; see also Inkelas 2014:22, 26).

Morphologically conditioned phonology is the phenomenon in which a particular phonological pattern is imposed on a proper subset of morphological constructions (affixation, reduplication, compounding) and thus is not fully general in the word internal phonological patterning of the language." (Inkelas 2014:9; cf. Inkelas 2011:69)

Turkologists make a similar distinction. For instance, Göksel and Kerslake's (2005) grammar has three parts: phonology, morphology, and syntax. Tellingly, Göksel and Kerslake treat vowel harmony $(\mathrm{VH})$ in the first part (Chapter 3 ) and less regular processes like stem-final $k$ deletion in the second part (Chapter 6 - Principles of suffixation). Is this distinction between "very general" phonology and morphologically conditioned phonology valid in Turkish? In a modular grammar, which component is responsible for MCP? We address these questions and conclude that even "very general" phonological processes such as VH are under the control of morphology in Turkish.

2. Vowel harmony in Turkish. VH is not fully general in Turkish, as is well-known. Consider the concise description of backness harmony in Inkelas (2011:69):

a very general rule of progressive vowel harmony determines the value of [back] for the vowels of most suffixes, which surface with front vowels following roots whose final

\footnotetext{
${ }^{*}$ Research for this article was supported by a fellowship to the first author from the Institute of International Education's Scholar Rescue Fund (IIE-SRF) and the University of Calgary (Faculty of Arts). We thank the article reviewers and participants of the Fifth Workshop on Turkic and Languages in Contact with Turkic (TU+5) in Newark, DE for their helpful feedback. Authors: Eyüp Bacanl,, University of Calgary (eyup.bacanli@ucalgary.ca), Darin Flynn, University of Calgary (dflynn@ucalgary.ca) \& Amanda Pounder, University of Calgary (apounder@ucalgary.ca).
} 
vowel is front (e.g., gyl-ler 'rose-PL', anne-ler 'mother-PL') but with back vowels following stems whose final vowel is back (e.g., ok-lar 'arrow-PL', elma-lar 'apple-PL').

Paraphrasing, VH does not actively apply to roots like anne 'mother' and elma 'apple' (\$2.1), nor does it determine the value of [back] in all suffix vowels $(\S 2.2)$.

2.1. VOWEL HARMONY IN ROOTS. In a corpus study, Kabak et al. (2008:9) found that the first two vowels of a root disagree in backness about a third of the time. ${ }^{1}$ Kabak (2011:2839) concludes: "Despite the overwhelming number of harmonic roots in Turkish, no vowel alternation can be observed in them. ... [They] are nothing more than static surface regularities." This viewpoint is shared by Clements and Sezer (1982), Bennink (1992), Krämer (2003), Polgárdi (2006), among others. As Clements and Sezer (1982) put it, "the burden of proof is on the linguist who wishes to demonstrate that roots are governed by vowel harmony at all" (p. 226).

Most suggestive of an active vowel harmony process are "some 200 bisyllabic forms in Turkish in which a high vowel in the second syllable alternates with $\emptyset$ " (Clements \& Sezer 1982:243). The high vowels in question pattern after the quality of preceding vowels, e.g. bejnbejin- 'brain', karn- karun- 'stomach', ilm- ilim- 'science' aln- alun- 'forehead', etc. As such, these alternating roots are widely described in this way: "epenthesis of a high vowel occurs in Turkish to repair illegal consonant clusters in codas" (Bellik 2018a:1); "the coda-repairing vowel participates obligatorily in vowel harmony" (ib., p. 4; our emphasis).

In addition to the forms in which allegedly epenthetic vowels are harmonic with the first root vowel, however, "[t]here are bisyllabic forms ... in which the alternating vowel does not show the expected backness harmony with the root vowel" (Clements \& Sezer 1982:243). Most (1)of these are Arabic in origin, e.g.:

$$
\begin{aligned}
& \text { adl- adil- 'justice', adzz- adziz- 'impotence', aht- ahit- 'testament', azm- } \\
& \text { azim- 'resolution', bahs- } \sim \text { bahis- 'bet', hadjm- } \sim \text { hadzim- 'volume', hadzz- hadziz- } \\
& \text { 'confiscation', kabr- } \sim \text { kabir- 'tomb', kavm- } \sim \text { kavim- 'tribe', kavs- } \sim \text { kavis- 'bow', } \\
& \text { nakl- nakil- 'transport', rahm- rahim- 'womb', etc. }
\end{aligned}
$$

This is unexpected if $\mathrm{VH}$ is an active phonological process of the language. Moreover, Turkish freely allows fricative+stop codas and sonorant+obstruent codas (Topbaş \& Kopkall1-Yavuz 2008:569), yet vowel alternations also occur within such clusters, as shown in (2). (These stems are mostly loanwords, too.) If "epenthesis of a high vowel occurs in Turkish to repair illegal consonant clusters" (Bellik 2018:1), it is unexpected that "the epenthetic vowel breaks up clusters which are otherwise permissible in Turkish" (Clements \& Sezer 1982:254, n. 21).

kast- kasut- 'intention, purpose' (cf. kast 'caste, intent', yst 'upper plane', dost 'close friend', etc.), laht- lahit- 'sarcophagus' (cf. taht 'throne'), ufk- ufuk- 'horizon' (cf. zevk 'pleasure', zift 'tar', afk 'love', etc.), kejf- kejif- 'pleasure' (cf. pejk 'satellite', tejp 'tape', etc.), kajt- kajut- 'record' (cf. tajt 'tights', bajt 'byte', majt 'mite', etc.), genz- geniz- 'nostril' (cf. lenz 'Lenz', bent 'weir', fans 'chance', etc.), etc.

Actually, loanwords show an even wider array of complex codas, including stop+fricative, stop+stop, sonorant+sonorant, and obstruent+sonorant. The fact that such clusters are not

\footnotetext{
${ }^{1}$ For simplicity, we follow Inkelas (2011) and Kabak et al. (2008) in focusing on backness harmony. The arguments and analyses presented and reviewed in this article largely extend to rounding harmony.
} 
systematically "repaired" with vowel epenthesis in modern Turkish suggests that alternating vowels like those in (3) should not be described in this way either.

$$
\begin{aligned}
& \text { aks- akis- 'echo, reflection' (cf. raks 'dance', faks 'fax', boks 'boxing', etc.), haps- } \\
& \sim \text { hapis- 'prison' (cf. dzips 'chips'), akt- akit- 'treaty', nakt- nakit- 'cash', vakt- } \\
& \text { vakit- 'time', sukt- sukwt- 'miscarriage' (cf. sekt 'sect', akt 'act', pakt 'pact, } \\
& \text { treaty', etc.), kajn- kajun- 'brother-in-law' (cf. ajn 'eye', etc.), karn- } \text { karmn- } \\
& \text { 'stomach' (cf. alarm 'alarm', farl 'Charles', etc.), kadr- kadir- 'worth', fikr- } \\
& \text { fikir- 'idea' (cf. titr 'title', lutr 'otter', etc.), etc. }
\end{aligned}
$$

In modern Turkish, then, it is not obvious that alternating vowels are "coda-repairing [epenthetic] vowels ... subject to vowel harmony" (Bellik 2018a:1). Rather, a subset of stems show "high vowel omission ... due to the attachment of a vowel-initial suffix" (Ketrez 2012:17). This lexically-restricted phonological process is best described synchronically as "vowel loss" according to Göksel and Kerslake (2011:29-30): "Some words have a different form when a vowel-initial suffix is attached to them than when they are bare. When suffixed with such a form, these words lose the vowel of their final syllable." 2

In fact, Erdal (2010) argues that high vowel syncope is a long-standing morphologically conditioned process in modern standard Turkish:

all originally Turkic stems which might seem to end in clusters in fact drop the vowel in their final syllable, belonging to one of two classes: They are either inalienables which are bound to have possessive suffixes, or they do so when followed by derivational suffixes with which they fuse. (p. 98)

That is, Erdal shows that high vowel syncope applies to certain Turkic-origin stems before many vowel-initial derivational suffixes, but this process does not accompany most vowel-initial inflectional suffixes - only possessive ones, contra Göksel and Kerslake (2011). The first author has conducted searches of Google and of the Turkish National Corpus which largely confirm Erdal's claim for Turkic stems.

By contrast with the native Turkic stems, stems with alternating high vowels "copied from other, Eastern or Western languages ... differ from the inalienables in that the form without vowel is used before all suffixes with vowel onset, including the dative: One says şehr-e 'to town' [cf. nominative şehir]" (Erdal 2010:97). Note that the vast majority of stems with alternating high vowels are Arabic in origin. It is worth mentioning, therefore, that a strikingly similar process occurs in many dialects of Arabic. For example, Egyptian Arabic has the following phonological rule: "V [+high, -back,-long] $\rightarrow \emptyset /$ VC_CV Stem Syncope" (Welden 1977:77; see also Kenstowicz 1980; Teeple 2009). In practice, this rule mostly applies with vowel-initial suffixes in Egyptian Arabic, e.g., firib-u $\rightarrow$ firbu 'they drank' (drank-3PL.MASC) (ib.). So it is tempting to assume that Turkish borrowed not only many Arabic stems, but also their wider participation in high vowel syncope. The fact remains, however, that high vowel syncope has long existed as a morphologically conditioned process within Turkish and Turkic more generally. "The phenomenon is old" (Erdal 2010:97) and "happens to a different extent in different Turkic languages; in Turkmen, e.g., vowel syncopation is much more general than in Turkish" (p. 93).

\footnotetext{
${ }^{2}$ For what it's worth, the vowel alternations are also described as vowel deletion by various Turkish teachers, e.g., https://www.turkishexplained.com/pocnoun.htm; https://www.scribd.com/document/263139461/5-Nouns-WhichLose-an-Internal-Vowel-in-Turkish; etc.
} 
In sum, stems with alternating high vowels offer little support for the view that Turkish actively repairs illegal consonant clusters by epenthesizing a vowel that obligatorily and automatically undergoes vowel harmony (pace Bellik 2018b, etc.). The fact that roots with two or more vowels are mostly harmonic is no more than a static fact about Turkish (Kabak 2011:2839).

2.2. VOWEL HARMONY IN SUFFIXES. VH does not determine the value of [back] in all suffix vowels. For example, the associative suffix -gil retains its front vowel even when the base ends in a back vowel (4) and the hypocoristic suffix - $o$ retains its back vowel even when the truncated base has a front vowel (5) (cf. Lewis 2000:15-16, 55; Göksel \& Kerslake 2005:59; Kabak 2011:2835).

$\begin{array}{llll}\begin{array}{l}\text { kuna-gil-ler' } \\ \text { henna-ASSOC-PL } \\ \text { 'lythraceae' }\end{array} & \begin{array}{l}\text { domuz-gil-ler } \\ \text { pig-ASSOC-PL } \\ \text { 'suidae' }\end{array} & \begin{array}{l}\text { tavfan-gil-ler } \\ \text { rabbit-ASSOC-PL } \\ \text { 'leporids' }\end{array} \\ \begin{array}{l}\text { syl-o } \\ \text { mëleyman-HYP }\end{array} & \begin{array}{l}\text { Mehmet-HYP } \\ \text { 'Süleyman' }\end{array} & \begin{array}{l}\text { ib-o } \\ \text { Ibrahim-HYP }\end{array} & \text { dJem-o } \\ \text { 'Mehmet'4 } & \text { 'Ibrahim' } & \text { 'Cemâl-HYP }\end{array}$

Moreover, certain suffixes are only half-harmonizing. For example, the adjectival suffix -imtrak (6) and the verbal progressive suffix -ijor (7) show VH in their initial vowels but their second vowels are invariably back (cf. Underhill 1976:112-113; Lewis 2000:55; Göksel \& Kerslake 2005:44).

$\begin{array}{lll}\text { jefil-imtrak } & \text { kuzul-umtrak } & \begin{array}{l}\text { esmer-imtrak } \\ \text { green-ish }\end{array} \\ \text { 'greenish' } & \text { red-ish } & \text { brown-ish } \\ \text { brownish' }\end{array}$

$\begin{array}{llll}\text { gel-ijor-um } & \text { atf-ujor } & \text { iff-ijor-sun } & \text { jap-ujor-lar } \\ \text { come-PROG-1SG } & \text { open-PROG } & \text { drink-PROG-2SG } & \text { build-PROG-PL } \\ \text { 'I'm coming' } & \text { 'he is opening' } & \text { 'you're drinking' } & \text { 'they're building' }\end{array}$

Conversely, the possibility suffix -(j)abil (8) and the non-premeditative suffix -(j) uver (9) show VH in their first vowels but their second vowels are invariably front (Underhill 1976:405; Lewis 2000:191; Göksel \& Kerslake 2005:141).

jaz-abil-
write-PSB-
'could write'
kapa-juver-
close-AUX-
'close suddenly'

ji-jebil-
eat-PSB-
'could eat'
gir-iver-
enter-AUX-
'enter quickly'

\begin{tabular}{|c|c|}
\hline $\begin{array}{l}\text { konu } \int-a b i l- \\
\text { talk-PSB- } \\
\text { 'able to talk' }\end{array}$ & $\begin{array}{l}\text { gør-ebil- } \\
\text { see-PSB- } \\
\text { 'manage to see' }\end{array}$ \\
\hline $\begin{array}{l}\text { ur-uver- } \\
\text { ve-AUX- } \\
\text { ve quickly' }\end{array}$ & $\begin{array}{l}\text { gid-iver- } \\
\text { go-AUX- } \\
\text { 'to go quickly, dash' }\end{array}$ \\
\hline
\end{tabular}

Finally, certain suffixes that normally undergo VH (e.g., plural -ler) fail to do so with certain roots. Notably, "there is a fairly large set of back vowel stems ... which require front vowel suffixes" (Clements \& Sezer 1982:241), e.g. (10). Clements \& Sezer (ib.) suggested that these roots are not really exceptional - they end in palatalized consonants. This suggestion receives strong

\footnotetext{
${ }^{3}$ We follow Göksel and Kerslake (2011) and Göknel (2012) among others in transcribing all alternating vowels as front and unrounded.

4 "The $\mathrm{h}$ in the common masculine name Mehmet is silent in standard Turkish" (Lewis 2000:5:5).
} 
support from Canalis \& Dikmen (to appear) who show in a preliminary study that "the palatal-

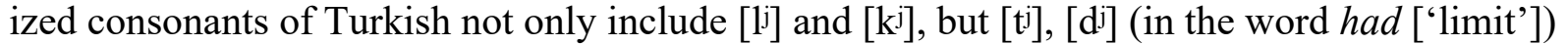
and $\left[\mathrm{r}^{\mathrm{j}}\right]$ (in final clusters) as well" (p. 13). ${ }^{5}$

$\begin{array}{lllll}\text { harp-ler } & \text { harf-ler } & \text { kalp-ler } & \text { rab-ler } & \text { sa:t-ler } \\ \text { war-PL } & \text { letter-PL } & \text { heart-PL } & \text { lord-PL } & \text { hour/clock-PL } \\ \text { 'wars' } & \text { 'letters' } & \text { 'hearts' } & \text { 'lords' } & \text { 'hours, clocks, watches' }\end{array}$

By contrast with the exceptional back-vowelled roots just described, there are no front-vowelled roots that systematically take back-vowelled suffixes (pace Clements \& Sezer 1982:242). ${ }^{6}$ This has led researchers who reject the marginal palatalized consonants proposed by Clements \& Sezer (1982:241) to conclude that alternating vowels are front by default (e.g. Kabak 2007, 2011; Kabak \& Vogel 2011; Göksel \& Kerslake 2011; Hankamer 2011; Göknel 2012; Bellik $2015){ }^{7}$ This in turn suggests that VH is actually progressive [+back] assimilation - or [Dorsal] spreading in Kabak \& Vogel's terms. On this view, the suffixes -o (5), -imtrak (6), and -ijor (7) above are not really "non-" or "half-harmonizing"; they simply have [+back]/[dorsal] vowels, which are therefore not targeted by [+back]/[Dorsal] spreading (Kabak \& Vogel 2011).

However, treating Turkish $\mathrm{VH}$ as $[+$ back]/[dorsal] spreading does not explain away the case of a front-vowelled suffix like -gil (4). This non-harmonizing suffix is not a lone example. Göksel and Kerslake (2005:24-25) also point to -izm '-ism' (e.g., Jaman-izm 'Shamanism'), -gen 'sided' (e.g., altu-gen 'hexagon'), -ki ' 's' (e.g., jarwn-ki 'tomorrow's'), -lejin '-ly/ADV' (e.g., sabah-lejin 'in the morning'), and -en '-ly' (e.g., tamam-en 'completely').

The net impression provided by suffix data is that VH is morphologically conditioned: it does not accompany all suffixes and it only applies across the stem-suffix boundary, as in (11). VH does not apply across vowels inside suffixes, e.g. (6-9), just as it does not apply across vowels inside roots $(\S 2.1){ }^{8}$

$$
\mathrm{VH}:[\alpha \mathrm{back}] \rightarrow[-\alpha \mathrm{back}] /[-\alpha \mathrm{back}]+
$$

The next section reviews attempts to restrict VH to the phonological component of Turkish grammar notwithstanding the numerous attested and well-documented exceptions.

3. Phonological approaches to vowel harmony in Turkish. Phonologists tend to set aside the fact that VH is not fully regular in Turkish (e.g. Kenstowicz 1994:26; Ewen \& Hulst 2001:46ff.; Gussman 2002:119ff.; Jensen 2004:269; Kaisse \& Levi 2004; Odden 2005:208ff.). Those who deal with this fact do so by enriching phonological theory with exceptional representations $(\S 3.1)$ or morphological information (\$3.2).

\footnotetext{
${ }^{5}$ The subjects in Canalis \& Dikmen's (to appear) acoustic study showed no palatalization in the final consonant of $/ \mathrm{rab} /$ 'God, lord' but this was expected: they inflected /rab/ with back-vowelled suffixes, e.g., rab-lar 'lords', contrary to the standard rab-ler (p. 12).

6 "Although Clements and Sezer (1982) note some velar consonants requiring suffix vowels as back even when preceded by front vowels, those items seem to be highly marginal and affix-specific, and hence their status and generalizability in contemporary Turkish are questionable (e.g. very marginally: /tasdik-u/ 'confirmation-POSs.3SG', commonly: /tasdik-i/, and never */tasdiklar/ but/tasdik-ler/ 'confirmation-PL' or */tasdik-suz/ but /tasdik-siz/ 'confirmation-DER', etc.)” (Kabak 2011:2846; see also Bellik 2015:92, fn. 18).

${ }^{7}$ Bellik (2015:92) traces the "default front suffix" view of Turkish back to Underhill (1976).

${ }^{8}$ In practice, there are suffixes in which two vowels participate in $\mathrm{VH}$, e.g. the nominal derivational suffix -(j)edzek $\sim-(j)$ adzak and the adjectival derivational suffix -(j)esi -(j)asu (Göksel \& Kerslake 2005:54-55). Under standard autosegmental assumptions, the vowels in such suffixes share a single [back] feature - as a static fact. A shared feature is changed, affecting both vowels, whenever VH applies across the stem-suffix boundary; see (11).
} 
3.1. EXCEPTIONAL PHONOLOGY. There is a long tradition of positing exceptional phonological elements to capture "non-automatic rules in generative phonology" (Gouskova 2012:81). For example, Bellik $(2015,2018 b)$ offers an account of the apparently exceptional roots in (10) by drawing on McCarthy's (2004) Span Theory. She claims that the back vowels in these roots are embedded in [+back] spans whereas the consonants are contained in larger [-back] spans, e.g., $\left(h(a)_{+ \text {back }} r p\right)_{\text {-back }}$ 'war'. She then argues that embedded spans cannot accommodate suffixes, e.g., *(h(arp-lar $\left.)_{+ \text {back }}\right)_{\text {back, }}$ whereas unembedded spans can do so, e.g., $\left(h(a)_{+ \text {back }} r p \text {-ler }\right)_{\text {-back }}$ 'wars'. In practice, the phonetic evidence for [-back] in these roots (Canalis \& Dikmen to appear) does not align with the proposed spans. More generally, pace McCarthy (2004), there is little independent justification in the phonological literature for the notion of feature spans - let alone embedded ones.

As another example of exceptional elements in phonological analysis, Kabak \& Vogel (2011) argue that Turkish has a fully general rule of [+back]/[Dorsal] spreading, as mentioned in $\S 2.2$. They claim that back vowels which fail to participate in VH are phonologically defective in carrying an "association line truncated with " $\mathrm{x}$ "” (p. 82), as illustrated in (12).

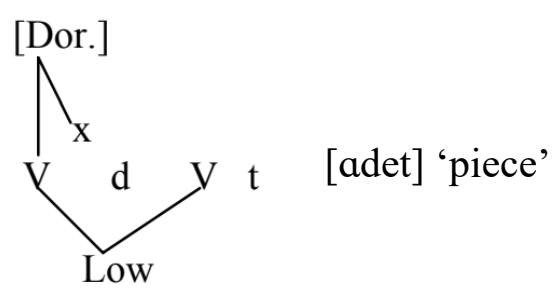

The mechanism whereby VH is "blocked by a truncated association line" (p. 83) is not obvious. As with Clements and Sezer's (1982) "opaque consonants" and Bellik's $(2015,2018 b)$ "feature spans," there is no phonetic evidence for a distinction between back vowels with and without truncated association lines. Nor is there phonological evidence - independent of the fact that a front vowel follows - that these back vowels have truncated associated lines. Moreover, the very notion that a distinctive feature may carry a truncated associated line as in (12) is not independently motivated in phonological theory. This ad hoc representation is not part of "the furniture of the world," as Bromberger and Halle (2000:36) put it.

Gouskova (2012) argues that phonological theory should dispense with exceptional segments altogether. One of her cautionary examples is stop voicing in Turkish. She observes that suffixes such as ablative -ten assimilate in voicing to a preceding sound, whereas other suffixes do not alternate in this way, e.g., relative - $k i$ remains voiceless while -gen '-sided' remains voiced. Inkelas and Orgun (1995) and Inkelas et al. (1997) propose that alternating stops lack a [voice] specification whereas non-alternating stops are specified [-voice] or [+voice]. This is comparable to Clements and Sezer's (1982:241-3) distinction between [-back] vs. [+back] vs. [Øback] consonants in Turkish. Similarly, Kabak (2011:2838-2839) distinguishes [-back] vs. [+back] vs. [Øback] vowels in Turkish VH.

There is no independent evidence for any of these three-way contrasts in Turkish consonants or vowels, and Gouskova warns that they make incorrect predictions. Consider a possible suffix like -tat in which the first stop is [ $\emptyset$ voice] while the second is [-voice]. Such a suffix would display

intervocalic voicing on the left but not on the right ... voicing agreement on the left [but] no voicing agreement on the right. Turkish does not have any suffixes of this kind - all 
either alternate or do not. Thus I conclude that Turkish does not provide clear evidence for segment-by-segment marking. (Gouskova 2012:121)

More generally, too, "ternary power" in featural representations has long been considered undesirable in phonological theory (cf. e.g. Lightner 1965, 1972; Stanley 1967; Kiparsky 1982b; Pulleyblank 1986).

In short, phonologists are free to model irregular processes with exceptional representations, but to be convincing, the representations in question must be supported by evidence that is independent of the fact being modelled. Such has not been the case in strictly phonological approaches to Turkish.

3.2. MoRPHOLOGY IN PHONOLOGY. The preceding section illustrated the use of exceptional phonological representations to capture processes like $\mathrm{VH}$ which are not fully regular. Another tack among phonologists is to allow the phonological component to refer to morphological information (Chomsky \& Halle 1968 et seq.). For example, Kardestuncer (1982) proposes SPE-style rules for Turkish VH which make crucial reference to morphological boundaries. Some authors maintain that $\mathrm{VH}$ is general in Turkish but is blocked in certain morphological contexts. Bennink (1992) and Polgárdi (2006) claim that VH is blocked in morphologically-defined "single analytic domains," notably roots (cf. Mascaró 1976). Similarly, Krämer (2003) claims that a correspondence-theoretic constraint (McCarthy \& Prince 1999) blocks VH in Turkish roots. Finley (2010) argues instead that a correspondence-theoretic constraint blocks $\mathrm{VH}$ in a select group of morphemes in Turkish.

Note that most recent analyses are set in Optimality Theory (Prince \& Smolensky 1993), which allows phonological constraints to be indexed to particular morphological domains (McCarthy \& Prince 1993; Jurgec \& Bjorkman 2018), lexical classes (Itô \& Mester 1995, 2001; Smith 2001), or morphemes (Pater 2000, 2007, 2009; Becker \& Potts 2011; Gouskova 2012). Of special interest is that all such morphologically-indexed constraints apply to the output representations of phonology - Optimality Theory does not constrain input representations at all. It is unusual to locate the morphology-phonology interface at the output of the phonological component. In a classical modular understanding of language ( cf. e.g. Pierrehumbert 2002), "morphology "feeds into" phonology, causing alternation when the right phonological rules are present" (Hayes 2009:130). The output of phonology is expected to interface with the phonetic component instead (cf. e.g. Boersma 2011). If the output representations of phonology abound in morphological information, what then prevents an abundance of morphologically conditioned phonetics? (see Bermúdez-Otero 2010 for discussion).

To avoid broad issues of grammatical architecture as just described, Inkelas et al. (1997), Anttila (1997, 2002), Yu (2000), and Inkelas and Zoll (2007) argue that morphological constructions, lexical classes, and morphemes are not directly indexed in phonological constraints, but rather assorted into multiple phonological grammars, or co-phonologies. Kabak and Vogel (2011:70-73) sketch a cophonology analysis of Turkish VH but they rightly warn that

as soon as a grammar divides morphemes into distinct classes based on some detectable pattern [including "static regularities" (ib. 64)], it permits the proliferation of (potentially uninteresting) co-phonologies. (p. 72)

Kabak and Vogel observe that phonological analyses which access morphology may also make use of idiosyncratic phonological representations (cf. §3.1). For example, Inkelas et al.'s (1997) co-phonology account of voicing alternations in Turkish relies on a three-way voicing contrast in stops: [-voice] vs. [+voice] vs. [Øvoice]. Gouskova (2012) reanalyzes these alternations with 
morpheme-indexed phonological constraints but maintains a three-way distinction in stops, after Kallestinova (2004): [spread glottis] vs. [voice] vs. $\emptyset$. In reality, only a two-way laryngeal contrast is well-motivated in Turkish phonology.

Altogether, a broader presumption is apparent among phonologists, whether they ignore the fact that VH is not fully regular in Turkish (e.g., Kaisse \& Levy 2004), or deal with it by invoking exceptional representations (cf. e.g. Kabak \& Vogel 2011) or morphological information (e.g., Finley 2010):

No other cognitive module in a generative, innatist, modular framework is responsible for alternations - the [phonological component] bears all responsibility for generating them ... [T] he term 'alternation' here refers to any pair of morphologically related forms that give insight into the input, as determined by a particular theory (e.g. OT, SPE). (de Lacy 2009:49)

Morphologists beg to differ. The next section outlines a morphology-driven view of morphologically conditioned phonology.

4. Morphological approach to vowel harmony and other processes in Turkish. Morphologists hold phonology solely responsible for automatic phonological processes, but morphology directs phonology in the case of non-automatic phonological processes like VH which are morphologically conditioned. In such cases, "the morphology is the executive, phonology the executor" (Pounder 2000:36). On this view, a phonological process like VH in Turkish is under the control of morphology, so phonology need not account for why it does not apply inside roots (e.g., anne 'mother'), nor inside suffixes (e.g., progressive -ijor), nor for why it accompanies certain affixes (e.g., plural -ler), but not others (e.g., associative -gil).

There is no need for phonologists to posit exceptional representations such as an "association line truncated with "x"” (Kabak \& Vogel 2011:84) to prevent the application of VH in roots. Recall, too, that Kabak and Vogel account for half-harmonizing suffixes like adjectival -imtrak but not for fully non-harmonic suffixes like adverbial -lijen (\$2.2). The existence of both is expected if morphology is in control. The morphological operation that affixes -imtrak requires the application of $\mathrm{VH}$ whereas the morphological operation that affixes -lijen does not require this.

In what follows, we assume a modular grammar containing a dynamic morphological component responsible for the formation of complex words, distinct from the (static) lexicon. We assume further that the phonology contains a catalogue of non-automatic phonological processes that can only apply if specifically required and which is available to the morphology and the lexicon. Morphological operations may select a set of non-automatic phonological processes - one, several, all, or none of those eligible - to accompany them. Turkish affixations thus differ as to which of the eligible processes they access. The requirement for a given process to apply can be thought of as an instruction to the phonology (e.g., "Vowel Harmony!"), which can normally only set the process in motion when made to do so.

Table 1 below illustrates the fact that suffixes which are identical or similar in form or meaning may nonetheless vary in terms of what phonological processes accompany them. For instance, the morphological operation which affixes -dzik to noun bases and which associates it with diminutive semantic function includes information that it requires application of three nonautomatic phonological processes: vowel harmony, voicing assimilation, and prevocalic lenition. The operation affixing - dzik to adjective bases will, in contrast, direct phonology to apply six processes, including initial stress assignment, stem-final $k$ deletion, and vowel-insertion with monosyllabic roots. The phonology in each case need only be a relatively simple statement, 
referring only to phonological context. (Data are provided below Table 1 to illustrate the application $(\checkmark)$ and non-application $(X)$ of each phonological process with different affixations.)

\begin{tabular}{|c|c|c|c|c|c|c|}
\hline & 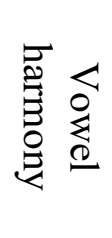 & 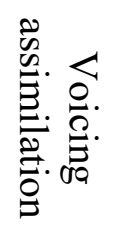 & 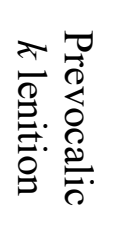 & 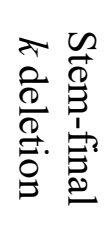 & 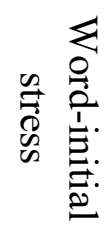 & 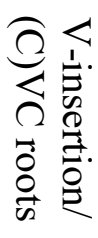 \\
\hline $\begin{array}{l}-d z i k \\
\text { DIM (ADJ) }\end{array}$ & $\checkmark$ & $\checkmark$ & $\checkmark$ & $\checkmark$ & $\checkmark$ & $\checkmark$ \\
\hline $\begin{array}{l}\text {-dzek } \\
\text { DIM (ADJ) }\end{array}$ & $\checkmark$ & $\checkmark$ & $\checkmark$ & $\checkmark$ & $x$ & $X$ \\
\hline $\begin{array}{l}\text {-dze } \\
\text { DIM (ADJ) }\end{array}$ & $\checkmark$ & $\checkmark$ & - & $X$ & $x$ & $X$ \\
\hline $\begin{array}{l}\text {-dzik } \\
\operatorname{DIM}(\mathrm{N})\end{array}$ & $\checkmark$ & $\checkmark$ & $\checkmark$ & $X$ & $x$ & $x$ \\
\hline $\begin{array}{l}\text {-aze:iz } \\
\operatorname{DIM}(\mathrm{N})\end{array}$ & $\checkmark$ & $x$ & - & $X$ & $x$ & $x$ \\
\hline $\begin{array}{l}-k i r^{9} \\
\text { ONOM (V) }\end{array}$ & $\checkmark$ & $x$ & - & $x$ & $x$ & $X$ \\
\hline $\begin{array}{l}-i \\
\text { HYPOCOR }\end{array}$ & $\checkmark$ & - & $X$ & $X$ & $x$ & $X$ \\
\hline $\begin{array}{l}-O \\
\text { HYPOCOR }\end{array}$ & $x$ & - & $X$ & $X$ & $\checkmark$ & $X$ \\
\hline $\begin{array}{l}-g i l \\
\operatorname{ASSOC}(\mathrm{N})\end{array}$ & $X$ & $X$ & - & $X$ & $x$ & $X$ \\
\hline
\end{tabular}

Table 1: Some phonological processes associated with a variety of suffixes in Turkish

(13) a. Vowel harmony

$\begin{array}{lllll}\checkmark & \text { elma } & \text { elma-dzík } & \text { søz } & \text { soz-dzýk } \\ \text { 'apple' } & \text { 'cheekbone' } & \text { 'saying' } & \text { 'word' } \\ \text { X } & \text { bakla } & \text { bakla-gil } & \text { turunt' } & \text { turunt-gil } \\ \text { 'bean' } & \text { 'legume' } & \text { 'bitter orange' } & \text { 'citrus' }\end{array}$

b. Voicing assimilation

\begin{tabular}{|c|c|c|}
\hline $\begin{array}{l}\text { kitáp } \\
\text { 'book' }\end{array}$ & $\begin{array}{l}\text { kitap-tfiúk } \\
\text { 'pamphlet' }\end{array}$ & $\begin{array}{l}\text { inék } \\
\text { 'cow', }\end{array}$ \\
\hline
\end{tabular}

${ }^{9}$ E.g. hajkur- 'shout', symkyr- 'blow one's nose' (cf. huttkur- 'hiccup', pyskyr- 'erupt'), etc. 


$\begin{array}{llll}\text { X } \quad \begin{array}{l}\text { kuf-dza:úz } \\ \text { 'bird' }\end{array} & \begin{array}{l}\text { inék } \\ \text { 'poor little bird' }\end{array} & \begin{array}{l}\text { inek-dze:iz } \\ \text { 'cow' }\end{array}\end{array}$

c. Prevocalic $k$ lenition
$\checkmark \quad k a z$-dzúk
'gosling'
(1s.poss)
kaz-dzwi-úm
$k ø k-t y \dot{k} \boldsymbol{k}$
$k ø k-t y:-y ́ m$
$X \quad$ ads-uk -
ads-uk-up
'root-let'
(1s.poss)
'hungry-VB'
'by being hungry'
gøz-yk-
'eye-VB'
gøz-yk-yr
'appears'

d. Stem-final $k$ deletion

$\begin{array}{lll}\checkmark & \text { ufák } & \text { úfa-dbuk } \\ & \text { 'small' } & \text { 'very small' } \\ & & \text { ufák-tfa } \\ & \text { 'quite small' }\end{array}$

kytfy'k
'small'

$k \dot{y} t y-d z y k$

'very small'

$k y t y$ ' $\boldsymbol{k}$-tfe

'quite small'

e. Word-initial stress

$\begin{array}{lll}\checkmark & \begin{array}{l}\text { juvarlák } \\ \text { 'round' }\end{array} & \begin{array}{l}\text { júvarla-dzuk } \\ \text { 'beady' }\end{array} \\ \times & \begin{array}{l}\text { byjýk } \\ \text { 'big' }\end{array} & \begin{array}{l}\text { byjy-dzék } \\ \text { 'a little big' }\end{array}\end{array}$

f. Vowel-insertion on (C)VC-shaped roots

$\begin{array}{lllll}\checkmark & \text { dar } & \text { dára-djuk } & a z & \text { '́zu-dzuk } \\ & \text { 'narrow' } & \text { 'quite narrow' } & \text { 'little' } & \text { 'a little bit' } \\ \times & a d & a d \text {-dzúk } & k a z & k a z \text {-dzúk } \\ & \text { 'name' } & \text { 'little name' } & \text { 'goose' } & \text { 'gosling' }\end{array}$

Table 1 and the accompanying data show not only that different affixations select different sets of phonological processes to accompany them, but also that these sets are tied to the operation (combination of form change, semantic function, and category (etc.) change) and not to individual derivations, that is, they are completely driven by the dynamic morphology and not lexically bound. This is unlike the situation in e.g. English Latinate derivational morphology, where the application of phonological concomitants of affixation often has to be lexically specified (cf. e.g. the application of "stress shift" in 'gelatine $\rightarrow$ ge 'latinize vs. 'hospital $\rightarrow$ 'hospitalize).

The data exemplifying Table 1 illustrate how morphology "feeds" or directs the phonology in a number of ways. First, morphological processes will almost always result in instructions to the phonology in some sense, the exception being identity processes that leave a base unchanged, e.g. the morphology can order the addition of an affix in a given position and it will be the phonology that actually has to do the work and carry out any automatic processes that apply as a consequence of the resulting sequences (these do not need to be referred to by the morphology). Second, in the case of non-automatic phonology, as in the six processes shown in Table 1, the morphology will give explicit instructions to the phonology to carry them out. Here we distinguish between modifications to the affix being added itself, resulting in affix allomorphy, as in the case of $\mathrm{VH}$, and modifications to the base, resulting in stem allomorphy, as in the case of $k$ deletion. Unless a modification is idiosyncratic, particular to just one form-change or operation, 
which is not the case here, it can be assumed that the phonological processes themselves exist in full detail in the phonology and need only be referred to or indexed as a general instruction in the relevant condition set of the morphological operation (e.g. "VH" in the form-rule condition set of an affix will suffice in the case of Turkish).

It can be further assumed that the format of the non-automatic phonological processes themselves does not differ from that of automatic ones, except for the conditioning: automatic processes will have phonological conditions and may also make reference to word-boundaries etc., while non-automatic ones, in addition to phonological conditions will have no others beyond the fact that they must be requested by lexicon or morphology.

5. Note on the origin of morphologically conditioned phonology. Vowel harmony likely began as a phonetic, then strictly phonological process, but this was short-lived (cf. Dressler 1985:231). Early on, the resulting alternations became associated with concatenation - a mainstay in an agglutinative language. They served an important function, therefore, of delimiting words in the speech stream and more generally, signalling the presence of morphological structure. These alternations then became properties of the relevant morphological processes, on the one hand, and independently of this, the phonological process of $\mathrm{VH}$ lost its status as active in the phonology. Non-harmonic roots and the treatment of integrated loan-words whereby the vowels are not harmonized show that VH ceased being automatic very early on. Given the new role of $\mathrm{VH}$ in the morphology and its loss of status in the phonology, $\mathrm{VH}$ became a phonological process under the control of the morphology.

Other frequent processes like $k$ lenition were likely never general phonological processes. For instance, at no point in time did Turkish ever rid itself of all prevocalic $k$ 's through lenition. Rather, a process of leniting $k$ upon addition of a vowel-initial suffix would always have been associated with specific morphological operations and thus would have been a phonological process under the control of morphology from the beginning. Like $\mathrm{VH}$, it served the function of signalling concatenation and thus word-structure, supporting word-level cohesion. It is not the case, therefore, that all morphologically-conditioned phonology goes through all stages of the morphologization process, from phonetic conconcomitant $\rightarrow$ automatic phonological process $\rightarrow$ non-automatic phonological process/incipient morphologization ( $\rightarrow$ morphological process).

6. Conclusion. Inkelas (2011:68) draws a distinction between regular phonological processes like VH ("a very general rule ... for the vowels of most suffixes") and morphologically conditioned ones like stem-final $k$ deletion, e.g. (13d). This distinction matters little in practice, given the presumption that the phonology is fully responsible for both kinds of alternation. Moreover, this distinction is gradient at best. VH is a static fact of most polysyllabic roots and affixes, yet disharmonic morphemes abound, e.g., anne ... kalk-abil-di 'mother ... managed to stand up' (Göksel \& Kerslake 2005:24). Thus, the only solid evidence that VH is an active process comes from vocalic alternations in suffixes and enclitics. But VH is not obligatory in concatenation either: over a dozen suffixes and clitics never show VH (ib.). Similarly, voicing assimilation (13b) and prevocalic $k$ lenition are widespread but not obligatory in Turkish suffixation, and conversely, other word formation processes are accompanied by restricted processes such as initial stress, stem-final $k$ deletion, and vowel-insertion with monosyllabic roots. All such processes represent morphologically conditioned phonology.

In conclusion, $\mathrm{VH}$ at least likely began as a phonologically motivated process, but eventually its phonological raison d'être became obsolete as its effects turned into static facts about Turkish words. In the meantime, its alternations became associated with concatenation, a mainstay in an agglutinative language. Morphology is unlike other modules of grammar in requiring 
access to all of syntactic, semantic, and phonological properties to function, as restricted phonological processes attest. One of the roles of morphology is to give commands to the phonology during formation of a complex word, such as "Carry out VH!" The phonology need not account for why such a command does not accompany certain suffixes, why it does not apply to all roots, nor why other commands only accompany a few suffixes. More generally, there is no need for phonology to access morphological information in a modular model of grammar. We therefore suggest an analysis in which morphology and lexicon control VH and other non-automatic phonological processes, which are thus claimed to be no longer part of the active phonology of Turkish. The formalism and details behind our morphological analysis of morphologically conditioned phonology will be developed and shared in future work.

\section{References}

Anttila, Arto. 1997. Deriving variation from grammar. In Frans Hinskins, Roeland van Hout \& W. Leo Wetzels (eds.), Variation, change and phonological theory. 35-68. Amsterdam and Philadelphia: John Benjamins. https://doi.org/10.1075/cilt.146.04ant

Anttila, Arto. 2002. Morphologically conditioned phonological alternations. Natural Language and Linguistic Theory 20(1). 1-42. https://doi.org/10.1023/A:1014245408622

Becker, Michael \& Kathryn Flack Potts. 2011. The emergence of the unmarked. In Marc van Oostendorp, Colin Ewen, Elizabeth Hume \& Keren Rice (eds.), The Blackwell companion to phonology, vol. 3. 1363-1379. Hoboken: Wiley-Blackwell.

https://doi.org/10.1002/9781444335262.wbctp0058

Bellik, Jennifer. 2015. Feature domains and covert harmony in Turkish: the exceptional transparency of /a/. Santa Cruz, CA: University of California Santa Cruz MA thesis. https://escholarship.org/uc/item/36z9d814

Bellik, Jennifer. 2018a. An acoustic study of vowel intrusion in Turkish onset clusters. Laboratory Phonology 9(1). 16. http://doi.org/10.5334/labphon.112

Bellik, Jennifer. 2018b. Feature domains and lexically conditioned harmony in Turkish. In Faruk Akkuş, İsa Kerem Bayırlı \& Deniz Özyıldız (eds.), Tu+1: Proceedings of the first workshop on Turkish, Turkic and the languages of Turkey. 17-26. Amherst: GLSA. http://deniz.fr/pdfs/tuplusone.pdf

Bennink, Clemens. 1992. Harmony and disharmony in Turkish. In Reineke Bok-Bennema \& Roeland Van Hout (eds.), Linguistics in the Netherlands 1992. 25-36. Amsterdam: John Benjamins. https://doi.org/10.1515/tlir.1999.16.2.187

Bermdez-Otero, Ricardo. 2010. Morphologically conditioned phonetics? Not proven. Paper presented at the On Linguistic Interfaces II, University of Ulster, Belfast, Dec. 2-4, 2010. http://www.bermudez-otero.com/Belfast_handout.pdf

Boersma, Paul. 2011. A programme for bidirectional phonology and phonetics and their acquisition and evolution. In Anton Benz \& Jason Mattausch (eds.), Bidirectional Optimality Theory. 33-72. Amsterdam, The Netherlands: John Benjamins.

https://doi.org/10.1075/la.180.02boe

Bromberger, Sylvain \& Morris Halle. 2000. The ontology of phonology (revised). In Noel Burton-Roberts, Philip Carr \& Gerard Docherty (eds.), Phonological knowledge: conceptual and empirical issues. 19-37. Oxford, UK: Oxford University Press.

Canalis, Stefano \& Furkan Dikmen. to appear. Turkish palatalized consonants and vowel harmony. Proceedings of the Workshop on Turkic and Languages in Contact with Turkic 5. https://journals.linguisticsociety.org/proceedings/index.php/tu 
Chomsky, Noam \& Morris Halle. 1968. The sound pattern of English. New York: Harper \& Row.

Clements, G. N. \& Engin Sezer. 1982. Vowel and consonant disharmony in Turkish. In Harry van der Hulst \& Norval Smith (eds.), The structure of phonological representations II. 213255. Dordrecht: Foris. https://doi.org/10.1075/avt.9.05ben

de Lacy, Paul. 2009. Phonological evidence. In Steve Parker (ed.), Phonological argumentation: essays on evidence and motivation. 43-78. London: Equinox.

Dressler, Wolfgang. 1985. Morphonology: the dynamics of derivation. Ann Arbor: Karoma.

Erdal, Marcel. 2010. Inalienability and syncopation in Turkish. In Hendrik Boeschoten \& Julian Rentzsch (eds.), Turcology in Mainz - Turkologie in Mainz. 147-153. Wiesbaden: Harrassowitz.

Ewen, Colin J. \& Harry van der Hulst. 2001. The phonological structure of words: an introduction. Cambridge, UK: Cambridge University Press.

Finley, Sara. 2010. Exceptions in vowel harmony are local. Lingua 120(6). 1549-1566. https://doi.org/10.1016/j.lingua.2009.10.003

Göknel, Yüksel. 2012. Turkish grammar: updated academic edition. Istanbul: Vivatinell Press.

Göksel, Aslı \& Celia Kerslake. 2005. Turkish: a comprehensive grammar. New York: Routledge.

Göksel, Aslı \& Celia Kerslake. 2011. Turkish: an essential grammar. New York: Routledge.

Gouskova, Maria. 2012. Unexceptional segments. Natural Language and Linguistic Theory 30(1). 79-133. https://doi.org/10.1007/s11049-011-9142-4

Gussman, Edmund. 2002. Phonology: analysis and theory. Cambridge: Cambridge University Press.

Hankamer, Jorge. 2011. Turkish vowel epenthesis. In Eser Erguvanl1-Taylan \& Bengisu Rona (eds.), Puzzles of language: essays in honour of Karl Zimmer. 55-70. Wiesbaden: Harrassowitz .

Hayes, Bruce. 2009. Introductory phonology. West Sussex, UK: Wiley-Blackwell.

Inkelas, Sharon \& Cemil Orhan Orgun. 1995. Level ordering and economy in the lexical phonology of Turkish. Language 71(4). 763-793. https://doi.org/10.2307/415744

Inkelas, Sharon \& Cheryl Zoll. 2007. Is grammar dependence real? A comparison between cophonological and indexed constraint approaches to morphologically conditioned phonology. Linguistics 45(1). 133-171. https://doi.org/10.1515/LING.2007.004

Inkelas, Sharon, Cemil Orhan Orgun \& Cheryl Zoll. 1997. The implications of lexical exceptions for the nature of grammar. In Iggy Roca (ed.), Derivations and constraints in phonology. 393-418. Oxford: Oxford University Press. https://doi.org/10.1002/9780470756171.ch31

Itô, Junko \& Armin Mester. 1995. The core-periphery structure of the lexicon and constraints on reranking. In Jill Beckman, Laura Walsh Dickey \& Suzanne Urbanczyk (eds.), Papers in Optimality Theory: University of Massachusetts Occasional Papers 18. 181-210. Amherst: GLSA Publications.

Itô, Junko \& Armin Mester. 2001. Covert generalizations in Optimality Theory: the role of stratal faithfulness constraints. Studies in Phonetics, Phonology, and Morphology 7. 273-299.

Jensen, John T. 2004. Principles of generative phonology: an introduction. Amsterdam, The Netherlands: John Benjamins.

Jurgec, Peter \& Bronwyn Bjorkman. 2018. Indexation to stems and words. Phonology 33(4). 577-615. https://doi.org/10.1017/s0952675718000210 
Kabak, Barış. 2007. Hiatus resolution in Turkish: an underspecification account. Lingua 117(8). 1378-1411. https://doi.org/10.1016/j.lingua.2006.04.010

Kabak, Barış. 2011. Turkish vowel harmony. In Marc van Oostendorp, Colin J. Ewen, Elizabeth Hume \& Keren Rice (eds.), The Blackwell companion to phonology, vol. 5. 2831-2854. Hoboken: Wiley-Blackwell. https://doi.org/10.1002/9781444335262.wbctp0118

Kabak, Barış \& Irene Vogel. 2011. Exceptions to stress and harmony in Turkish: co-phonologies or prespecification? In Horst Simon \& Heike Weise (eds.), Expecting the unexpected: exceptions in grammar. 59-94. Berlin: Mouton de Gruyter.

Kabak, Barış, Eva Kasselkus, Kazumi Maniwa \& Silke Weber. 2008. Vowel harmony has direction and context: a corpus study. Paper presented at the 16th Manchester Phonology Meeting, Manchester.

Kaisse, Ellen M. \& Susannah V. Levi. 2004. Vowel harmony: nucleus to nucleus or vocalic node to vocalic node? Paper presented at the 78th Annual Meeting of the Linguistic Society of America, Boston.

Kallestinova, Elena. 2004. Voice and aspiration in Turkish stops. Folia Linguistica 38(1-2). 117-143. https://doi.org/10.1515/flin.2004.38.1-2.117

Kardestuncer, Aino. 1982. A three-boundary system for Turkish. Linguistic Analysis 10(2). 95117.

Kenstowicz, Michael. 1980. Notes on Cairene Arabic syncope. Studies in the Linguistic Sciences 10(2). 39-53.

Kenstowicz, Michael. 1994. Phonology in generative grammar. Oxford: Blackwell.

Ketrez, F. Nihan. 2012. A student grammar of Turkish. Cambridge: Cambridge University Press. Kiparsky, Paul. 1982a. Lexical phonology and morphology. In I. S. Yang (ed.), Linguistics in the Morning Calm, vol. 2. 3-91. Seoul: Hanshin.

Kiparsky, Paul. 1982b. Explanation in phonology. Dordrecht: Foris.

Krämer, Martin. 2003. Vowel harmony and Correspondence Theory. Berlin: Mouton de Gruyter. Lewis, Geoffrey. 2000. Turkish grammar, 2nd edn. Oxford, UK: Oxford University Press.

Lightner, Theodore. 1965. Segmental phonology of Modern Russian: MIT dissertation.

Lightner, Theodore. 1972. Problems in the Theory of Phonology. Edmonton: Linguistic Research, Inc.

Mascaró, Joan. 1976. Catalan phonology and the phonological cycle. Bloomington: MIT dissertation.

McCarthy, John J. 2004. Headed spans and autosegmental spreading. Ms. University of Massachusetts, Amherst. https://scholarworks.umass.edu/linguist_faculty_pubs/42/

McCarthy, John J. \& Alan Prince. 1993. Generalized Alignment. In Geert Booij \& Jaap van Marle (eds.), Yearbook of morphology, 79-153. Dordrecht, The Netherlands: Kluwer.

McCarthy, John J. \& Alan Prince. 1999. Faithfulness and identity in prosodic morphology. In René Kager, Harry van der Hulst \& Wim Zonneveld (eds.), The prosody-morphology interface. 218-309. Cambridge: Cambridge University Press.

https://doi.org/10.1017/CBO9780511627729.008

Odden, David. 2005. Introducing phonology. Cambridge, UK: Cambridge University Press.

Pater, Joe. 2000. Non-uniformity in English secondary stress: the role of ranked and lexically specific constraints. Phonology 17(2). 237-274.

https://doi.org/10.1017/S0952675700003900

Pater, Joe. 2007. The locus of exceptionality: morpheme-specific phonology as constraint indexation. In Leah Bateman, Michael O’Keefe, Ehren Reilly \& Adam Werle (eds.), Papers in 
Optimality Theory III. 259-296. Amherst: GSLA.

https://rucore.libraries.rutgers.edu/rutgers-lib/42029/PDF/1/

Pater, Joe. 2009. Morpheme-specific phonology: constraint indexation and inconsistency resolution. In Steve Parker (ed.), Phonological argumentation: essays on evidence and motivation. 123-154. London: Equinox.

Pierrehumbert, Janet B. 2002. Word-specific phonetics. In Carlos Gussenhoven \& Natasha Warner (eds.), Laboratory Phonology 7. 101-139. Berlin: Mouton de Gruyter. https://doi.org/10.1515/9783110197105.1.101

Polgárdi, Krisztina. 2006. Vowel harmony: an account in terms of government and optimality. Utrecht: LOT. https://www.lotpublications.nl/Documents/003_fulltext.pdf

Pounder, Amanda. 2000. Processes and paradigms in word-formation morphology. Berlin: Mouton de Gruyter.

Prince, Alan \& Paul Smolensky. 1993. Optimality Theory: constraint interaction in generative grammar. New Brunswick: Rutgers University Center for Cognitive Science. https://scholar.colorado.edu/concern/reports/41687j32q

Pulleyblank, Douglas. 1986. Tone in lexical phonology. Dordrecht, The Netherlands: Kluwer.

Smith, Jennifer. 2001. Lexical category and phonological contrast. In Robert Kirchner, Joe Pater \& Wolf Wikely (eds.), PETL 6: Workshop on the Lexicon in Phonetics and Phonology. 6172. Edmonton: University of Alberta. http://roa.rutgers.edu/files/728-0305/728-SMITH-0-0.PDF

Stanley, Richard. 1967. Redundancy rules in phonology. Language 43(2). 393-436. https://www.jstor.org/stable/411542

Teeple, David. 2009. Syncope. In Kees Versteegh, Mushira Eid, Alaa Elgibali, Manfred Woidich \& Andrzej Zaborski (eds.), Encyclopedia of Arabic language and linguistics, vol. 4. 389391. Leiden: Brill. http://dx.doi.org/10.1163/1570-6699_eall_EALL_COM_0328

Topbaş, Seyhun \& Handan Kopkall1-Yavuz. 2008. Reviewing sonority for word-final sonorant + obstruent consonant cluster development in Turkish. Clinical Linguistics \& Phonetics 22(10-11). 871-880. https://doi.org/10.1080/02699200802175867

Underhill, Robert. 1976. Turkish grammar. Cambridge, MA: MIT Press.

Welden, Elizabeth Ann. 1977. Prosodic aspects of Cairo Arabic phonology. Austin: University of Texas, Austin Ph.D. dissertation.

Yu, Alan. 2000. Stress assignment in Tohono O'odham. Phonology 17(1). 117-135. https://doi.org/10.1017/S0952675700003845 